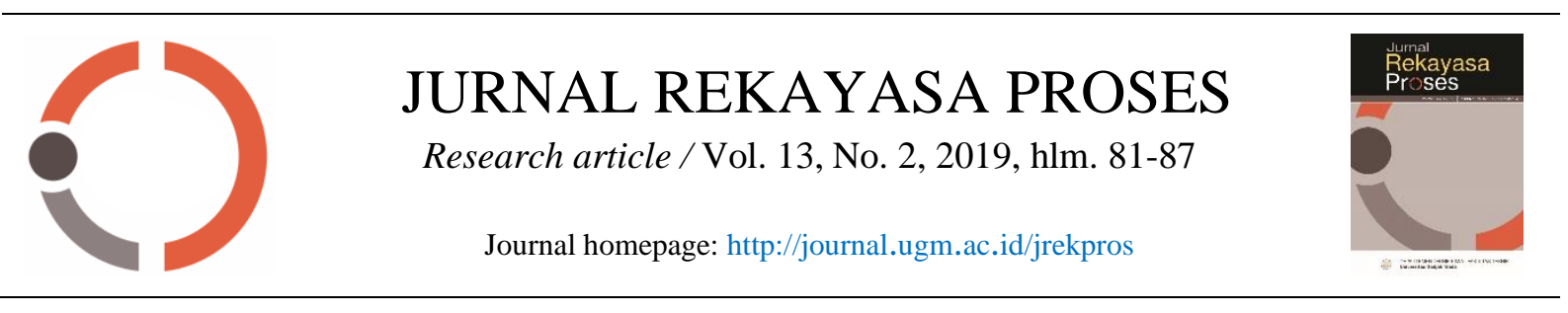

\title{
Comparative Study of Nyamplung (Callophylum inophyllum) Kernel Oil Obtained from Mechanical and Chemical Extraction for Biofuel Production
}

\author{
Hanifah Widiastuti ${ }^{1 *}$, Meiti Pratiwi ${ }^{2}$, Godlief F. Neonufa ${ }^{2,3}$, Tatang H. Soerawidjaja ${ }^{2}$, Tirto Prakoso ${ }^{2}$ \\ ${ }^{1}$ Department of Mechanical Engineering, Politeknik Negeri Batam, 29464 Batam, Indonesia \\ ${ }^{2}$ Department of Chemical Engineering, Institut Teknologi Bandung, 40132 Bandung, Indonesia \\ ${ }^{3}$ Department of Agriculture Product Technology, Universitas Kristen Artha Wacana, 85000 Kupang, \\ Indonesia \\ *Alamat korespondensi: hanifah@polibatam.ac.id
}

(Submission: January 18, 2019; Revision: March 18, 2019; Acceptance: March 21,2019)

\begin{abstract}
A B S T R A C T
Nyamplung (Callophylum inophyllum) contains oil around $40-73 \%$ in its seed. It has recently gained recognition as a potential source for biofuel production. The oil recovery process from renewable sources such as nyamplung is widely carried out by using chemical extraction with solvents. Nevertheless, this method is considered costly and there are safety issues as well as environmental concerns related to the solvents used. Therefore, mechanical extraction has emerged as an alternative method. In this study, the nyamplung oil recovered by mechanical extraction via hydraulic press and chemical extraction utilizing Soxhlet extraction was compared. Soxhlet extraction was carried out by using n-hexane as a solvent with a temperature of $70{ }^{\circ} \mathrm{C}$ for 5 hours. Before the extraction process, the kernel was initially pretreated to reduce the particle sizes and the water content. The results show that the oil yield recovered using the hydraulic press is $58 \%$, which is comparable with the value obtained from Soxhlet extraction (65\%). The oil characteristics were also compared, and the profiling shows no significant difference in the properties (saponification value, acid value, and iodine value) of oils recovered using both methods. The composition of fatty acids was also analyzed for utilization as a biofuel feedstock. Higher content of oleic acid was observed in oil resulted from chemical extraction while mechanical extraction yielded oil with higher palmitic acid content.
\end{abstract}

Keywords: biofuel; hydraulic press; nyamplung (Callophylum inophyllum); Soxhlet extraction

\section{A B STRAK}

Nyamplung (Callophylum inophyllum) mengandung minyak sebesar 40-73\% dalam bijinya dan belakangan ini diakui sebagai sumber potensial untuk pembuatan biofuel. Proses perolehan minyak nabati dari biji nyamplung pada umumnya dilakukan menggunakan ekstraksi kimia dengan pelarut. Akan tetapi, metode ini cenderung berbiaya tinggi serta memiliki isu berkaitan dengan keselamatan proses dan dampak lingkungan berkaitan dengan penggunaan pelarut. Oleh karena itu, metode ekstraksi mekanis banyak dikembangkan sebagai alternatif metode ekstraksi minyak. Dalam penelitian ini, hasil perolehan minyak nyamplung melalui penekanan hidrolik dibandingkan dengan hasil dari ekstraksi Soxhlet. Ekstraksi Soxhlet dilakukan dengan pelarut n-heksana pada suhu $70^{\circ} \mathrm{C}$ selama 5 jam. Sebelum proses ekstraksi, biji nyamplung mengalami perlakuan awal terlebih dahulu dengan cara digiling untuk mengurangi ukuran biji dan dipanaskan untuk mengurangi kadar air. Hasil yang diperoleh menunjukkan bahwa yield minyak dari ektraksi mekanik sebesar 58\% sementara yield dari ekstraksi Soxhlet adalah 65\%. Karakteristik minyak yang dihasilkan melalui kedua metode ini tidak 
menunjukkan perbedaan yang signifikan dalam hal nilai saponifikasi, nilai asam, dan nilai iodine. Analisis komposisi asam lemak dari kedua minyak yang dihasilkan menunjukkan bahwa minyak yang diperoleh dari ekstraksi kimia mengandung asam oleat dengan persentase yang lebih tinggi sementara minyak dari hasil ekstraksi mekanik memiliki persentase asam palmitat yang lebih tinggi.

Kata kunci: biofuel; ekstraksi Soxhlet; nyamplung (Callophylum inophyllum); penekanan hidrolik

\section{Introduction}

Dependence on fossil sources is currently one of the obstacles for meeting national energy demands. Nowadays, around $95 \%$ of energy generation relies on fossil sources as fuel (Dewajani et al., 2015). Fossil fuel sources are currently facing obstacles regarding reduced oil reserves, increasing fuel demand along with population growth, and the surging price of fossil fuel. Hence, these concerns of fossil fuels utilization have prompted the development of new energy sources as alternatives, including solar cells, geothermal power, wind power, nuclear, and biofuels.

A widely investigated source of biofuels is vegetable oils as alternatives to diesel fuel in the form of biodiesel and green diesel (biohydrocarbon). Based on the molecular formula of vegetable oils composition, the fatty acids contained in vegetable oils have many similarities to hydrocarbon compounds (Madsen, 2011). Thus, vegetable oils have the potential to become raw materials for the production of biofuels. At present, vegetable oils that are widely studied for biodiesel production are obtained from various crops such as palm oil, coconut oil, soybeans oil, sunflower oil, and rapeseed oil (Ramaraju and Ashok Kumar, 2011; Rizwanul Fattah et al., 2014; Sahoo et al., 2007; Sahoo and Das, 2009; Sari, 2013). The production of biofuels from these food crops has led to increasing food prices as well as causing competition of land use (Goldman Sachs Group, 2008).

Therefore, recent interest has emerged on the development of biofuels originating from nonfood crops. Some non-food crops that are considered attractive candidates are mabai/iron beach trees (Pongamia pinnata Merr), nyamplung (Calophyllum inophyllum), Jatropha curcas, and kapok (Ceiba pentandra) (Sahoo and
Das, 2009). The selection of plants that will be used as raw material for biofuels production depends on several factors including the availability at various locations and the ease of managing the crop. Based on these criteria, the raw material used in this study is nyamplung (Calophyllum inophyllum). Nyamplung has several advantages as a raw material for biofuels, mainly because the kernels contain a high percentage of fatty acids (around 40-73\%) (Dewajani et al., 2015). Almost all parts of the nyamplung plant can be utilized to produce various kinds of products that have economic values (Atabani and Cesar, 2014). Additionally, nyamplung forests could also function as windbreakers for crops (Ministry of Forestry of the Republic of Indonesia, 2008).

Nyamplung kernels contain triglycerides of long-chain fatty acids that have the potential to be processed into biofuels, especially biodiesel and green diesel (biohydrocarbons) (U.S. Department of Energy, 2007). To recover nyamplung oil from the kernels, there are several methods that could be carried out namely chemical extraction and mechanical extraction. The chemical extraction was carried out by using solvents, thus requiring subsequent solvent separation process. Several studies have been conducted by two-stage liquid extraction (Bhuiya et al., 2013), single stage extraction (Jahirul et al., 2015) and stirred single stage extraction (Kartika et al., 2017) with the oil yield of $51 \%, 40 \%$, and $59 \%$, respectively. Although chemical extraction could produce high oil yields, this method is considered very costly since it requires a solvent that ultimately becomes waste (Jahirul et al., 2013). There are also safety issues and environmental concerns regarding the use of solvents in chemical extraction.

Therefore, there have been emerging interests in the utilization of mechanical extraction since this method have several advantages over the 
chemical extraction namely no potential for solvent contamination, relatively inexpensive operating cost after the initial capital costs, and minor consumables cost (Jahirul et al., 2013). Nevertheless, the oil yield obtained from mechanical extraction was still inferior compared to the yield obtained from chemical extraction. The mechanical extraction studies utilizing screw press reported an oil yield of $28 \%$ by Bhuiya et al. (2013) and $18 \%$ by Jahirul et al. (2015). Therefore, this study aims to evaluate the yield of nyamplung oil obtained from mechanical extraction using hydraulic press pump and to compare the oil yield to the result from chemical extraction via Soxhlet extraction. Additionally, the compositions of the resulting oils are analyzed to provide information for designing the production process of nyamplung oil as a biofuels production feedstock.

\section{Research Methodology}

\subsection{Materials}

Nyamplung fruits used as the primary material in this research were obtained from Pemalang, Central Java, Indonesia. The solvents used are technical grade $n$-hexane and methanol obtained from PT Bratachem. Potassium hydroxide (99.9\% purity) used as a catalyst for the transesterification process was obtained from Merck, Germany.

\subsection{Procedures}

\subsubsection{Extraction process}

Before the oil recovery process, some pretreatments were conducted including cleaning, drying, seed recovery, and grinding. The first process was cleaning the harvested nyamplung fruits from gravel, twigs, fibers and other particles. This cleaning process was essential to prevent damage to the hydraulic pump due to impurities in the mechanical extraction process. Secondly, the nyamplung fruits were sun-dried to remove water content. The next step was cracking the nyamplung fruits to remove the shell and the pulp. Based on the proximate analysis results, the water content of nyamplung kernels reached $37 \%$. This water content needs to be removed before further processing. To ensure the minimal water content, the sample was weighed before and after drying. After drying, the dried nyamplung mass was approximately $60 \%$ of the initial wet mass. The drying process was conducted in the oven at $60{ }^{\circ} \mathrm{C}$ for 8 hours. After the nyamplung fruit kernels were moderately dried, the grinding process took place. Lastly, the ground nyamplung kernels was dried in the oven at $60{ }^{\circ} \mathrm{C}$ for 4 hours. The dry ground nyamplung kernels were then ready to be processed both via chemical and mechanical extraction.

In this study, the mechanical extraction was carried out using the principle of a hydraulic pump, while chemical extraction was carried out using Soxhlet. The hydraulic press pump was operated manually with the pressing chamber capacity of 100 grams ground kernels. The pressing process was carried out in ambient temperature. The ground nyamplung kernels were placed inside the pressing chamber then the chamber was closed. The lever was used to drive the piston up to press the ground nyamplung kernels so nyamplung oil was squeezed out into the oil collector part that led to the oil collection point as depicted in Figure 1 (a).

In the chemical method (Soxhlet extraction), the solvent used was n-hexane with the consumption rate of around $1.5 \mathrm{ml}$ solvent per gram of ground kernels. Soxhlet extraction was carried out at $70{ }^{\circ} \mathrm{C}$ for 5 hours based on the optimal extraction hours in a study reported by Kartika et al. (2017) and then followed with distillation to separate solvent (hexane) with nyamplung oil. The Soxhlet extraction apparatus utilized in this research is shown in Figure 1(b). The hexane-nyamplung oil mixture obtained from Soxhlet extraction was distilled at a temperature of $70{ }^{\circ} \mathrm{C}$ until there is no distillate drop collected (around 6 hours). Lastly, the resulting nyamplung oil (residue) was filtered using a vacuum pump to separate the sediment from the oil.

The nyamplung oil obtained either from mechanical or chemical extraction are still mixed with resin/sap requiring a subsequent separation step. This process was carried out using liquidliquid extraction by mixing the methanol with 
nyamplung oil with a solvent to oil ratio of 1: 1 (mass basis). The methanol-oil mixture was then put into a separating funnel and left for one (1) hour.

\subsubsection{Analysis methods}

To analyze the composition of the recovered nyamplung oil, the fatty acids in the oil must be converted to fatty acid methyl ester (FAME) through transesterification process. The nyamplung oil was reacted with $\mathrm{KOH}$ and methanol, then stirred for $1-2$ hours at $60{ }^{\circ} \mathrm{C}$. After being cooled, the mixture was put into a separating funnel, then left for one hour until it was separated into two phases. The obtained methyl ester fatty acids were then washed with demineralized water until the solution was neutral ( $\mathrm{pH} 7$ ). The resulting FAMEs were then analyzed using gas chromatography (Shimadzu 2010) with the capillary column (rtx-5) and mass spectroscopy. One microliter of sample was injected into the GC with a split ratio of $1: 100$ and the carrier gas (helium) flow rate was 42.9 $\mathrm{ml} / \mathrm{min}$. The injector and detector temperature were both $250{ }^{\circ} \mathrm{C}$.

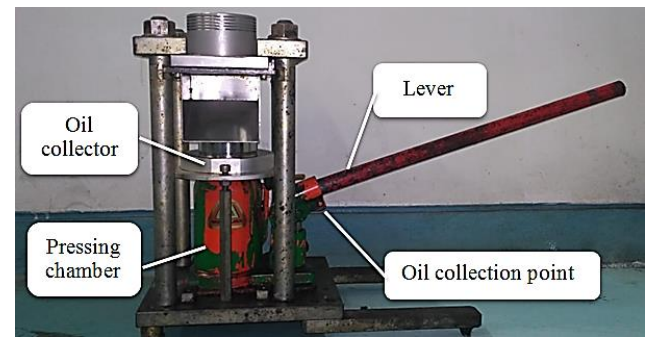

(a)
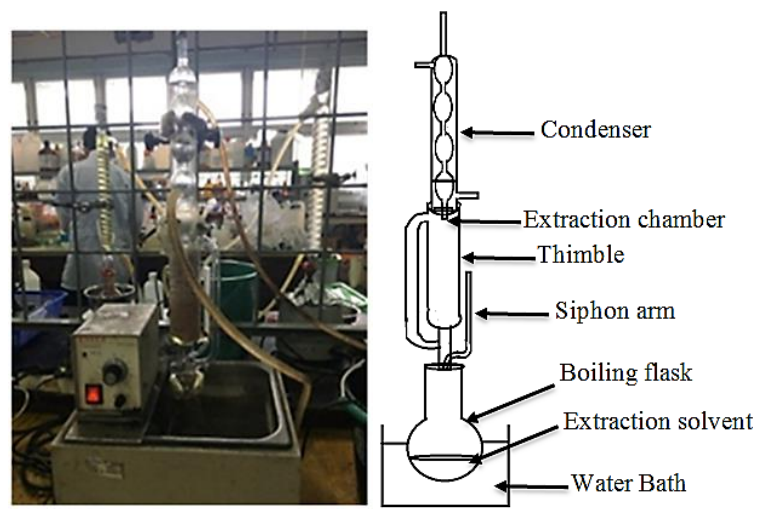

(b)

Figure 1. The process for obtaining oil from nyamplung fruit kernels, (a) by mechanical extraction, (b) by chemical extraction
The American Oil Chemists' Society (AOCS) methods were followed for the determination of the Acid Value (adapted from AOCS Method Cd 3d-63), Saponification Value (adapted from AOCS Method cd 3-25), and Iodine Value (adapted from AOCS Method Cd 1-25) of nyamplung kernels oil. Acid Value was determined by weighing two grams of the oil in $250 \mathrm{ml}$ Erlenmeyer flask. Neutral ethanols (20 ml) was added, shaken well, and titrated with $0.1 \mathrm{~N} \mathrm{KOH}$-ethanol using phenolphthalein as the indicator. Saponification Value was determined by weighing two grams of oil in $250 \mathrm{ml}$ Erlenmeyer flask, added $25 \mathrm{ml}$ of $0.5 \mathrm{~N} \mathrm{KOH}-$ ethanol, and the mixture was refluxed using aircondenser for one hour. After the flask was cooled, the condenser tip was washed with distilled water and the contents were titrated with $0,5 \mathrm{~N} \mathrm{HCl}$ using phenolphthalein as the indicator. A blank titration was carried out simultaneously.

Iodine Value is measured as the average amount of unsaturated fatty acids consisted of oil and fats; it is expressed in the form of centigrams of absorbed iodine per gram of sample (Knothe, 2002). Iodine Value was determined by weighing $0.2 \mathrm{~g}$ of the oil in $500 \mathrm{ml}$ flask and dissolved in chloroform. Wijs reagent was added into the mixture; the flask was stoppered and kept in the dark for one hour. Then $15 \%$ of KI solution and distilled water were added to the flask and mixed well. The mixture was titrated with $0.1 \mathrm{~N}$ sodium thiosulphate solution using starch solution as the indicator. A blank titration was also conducted

\section{Results and Discussion}

The nyamplung kernels before and after drying are depicted in Figure 2. The oil obtained from hydraulic press pump was around $58 \% \mathrm{~m} / \mathrm{m}$ while the Soxhlet extraction yield was $65 \% \mathrm{~m} / \mathrm{m}$. The lower yield for mechanical extraction might be caused by some oil that was left in the cake of the ground nyamplung kernels, on the pressing chamber's wall, and in the channels connecting pressing chamber to the collection point. The oil yield obtained from mechanical extraction in this study was higher than the oil yield obtained using 
a screw press in the study reported by Jahirul et al. (2013).

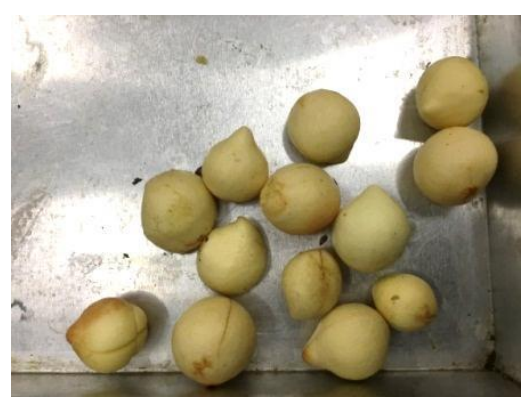

(a)

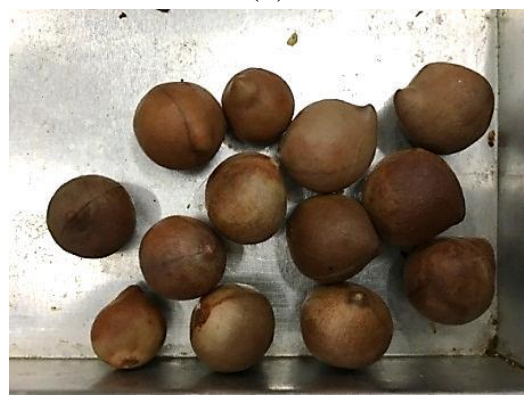

(b)

Figure 2. Nyamplung kernels, (a) Before drying with oven, (b) After drying with oven and before grinding

The properties of nyamplung oil recovered through both extraction processes are presented in Table 1, and the resulting nyamplung oil was depicted in Figure 3. The significant decrease of the acid value of nyamplung oil before and after methanol extraction could be attributed to the removal of resin that gives the green color in nyamplung oil before methanol extraction. This resin contained polar components and was diluted to methanol, a polar solvent, during the extraction process. The oil obtained from chemical method before methanol extraction has slightly higher acid values probably due to higher polar components in the resin obtained in the chemical extraction. These polar components were removed in the methanol liquid-liquid extraction resulting in a lower acid value in the oil from the chemical recovery compared to the oil from mechanical recovery. The resulting nyamplung oil (after methanol extraction) could be considered as clean oil and relatively free from resin since the acid values are quite low compared to the oils obtained from other studies (24 mg KOH/g by Jahirul et al. (2015) and 29.2 mg KOH/g by Hasibuan et al. (2013). The acid value is one of the important parameters of vegetable oil quality. Lower acid values mean a higher quality of oils because the oils would be more stable and have longer shelf storage (Dasari and Goud, 2013).

Another important parameter of vegetable oils quality is iodine number, especially related to its usage as biofuel. The vegetable oils that could be considered as biofuel should have iodine value lower than $115 \mathrm{mg}$ Iod/g (Kartika et al., 2010). The oils with higher iodine value tend to be unstable in high temperature thus could cause deposition in injection nozzle, piston, and other parts in diesel machine. Based on the results, the iodine value of nyamplung kernel oil obtained from mechanical extraction is relatively similar to the oil from chemical extraction (97 and $98 \mathrm{mg}$ Iod/g). Thus, nyamplung oil has potential as biofuel either through direct utilization as Pure Plant Oil (PPO) or further processing to produce biohydrocarbons.

Tabel 1. Properties of nyamplung kernel oil obtained from mechanical (hydraulic process) and chemical (Soxhlet) recovery process

\begin{tabular}{lcccc}
\hline \multirow{2}{*}{ Properties } & \multicolumn{2}{c}{$\begin{array}{c}\text { Mechanical } \\
\text { recovery }\end{array}$} & \multicolumn{2}{c}{$\begin{array}{c}\text { Chemical } \\
\text { recovery }\end{array}$} \\
\cline { 2 - 5 } & $\begin{array}{c}\text { Before } \\
\text { methanol } \\
\text { extraction }\end{array}$ & $\begin{array}{c}\text { After } \\
\text { methanol } \\
\text { extraction }\end{array}$ & $\begin{array}{c}\text { Before } \\
\text { methanol }\end{array}$ & $\begin{array}{c}\text { After } \\
\text { methanol } \\
\text { extraction }\end{array}$ \\
extraction \\
\hline $\begin{array}{l}\text { Saponification } \\
\text { value }\end{array}$ & 196.94 & 190.98 & 196.1 & 195.1 \\
Acid value & 26.86 & 6.88 & 33.79 & 5.89 \\
Iodine value & 97.12 & 85.51 & 98.75 & 83.3 \\
\hline
\end{tabular}

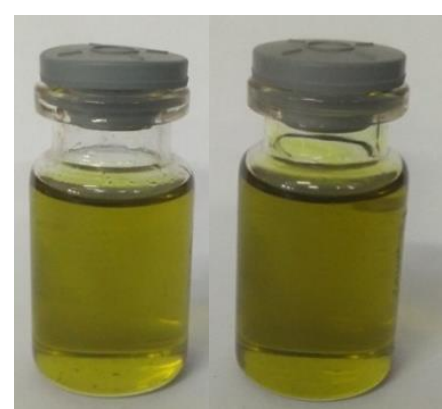

(a)

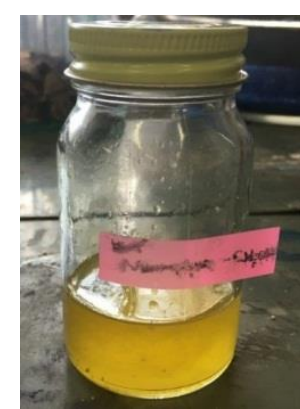

(b)
Figure 3. Nyamplung kernel oil, (a) before methanol extraction from mechanical extraction (left) and chemical/Soxhlet extraction (right), (b) after methanol extraction 
The fatty acids content in nyamplung kernels could differ from one source to another. Hence, for the utilization as a biofuel feedstock, analysis of the nyamplung oil composition is necessary. The analysis was carried out following the procedure as described in the Method section and the results are presented in Table 2. It can be seen that the major components of nyamplung oil for both mechanical and chemical extraction are oleic, linoleic, stearic, and palmitic acids. This composition of nyamplung oil is in accordance with other reports with the variation of percentage for different fatty acids (Atabani and Caesar, 2014). Additionally, slight variations in the composition percentages are also observed between different extraction methods of nyamplung oil. In this study, chemical extraction yielded higher oleic acid compared to mechanical extraction while the opposite result obtained for palmitic acid. This observation is probably due to the use of n-hexane, a non-polar solvent, in chemical extraction that has higher affinity with oleic acid (non-polar fatty acid) compared to palmitic acid (polar fatty acid).

Table 2. Major components of nyamplung fruit kernel oil obtained from mechanical (hydraulic process) and chemical (Soxhlet) recovery process

\begin{tabular}{ccccc}
\hline $\begin{array}{c}\text { Compounds } \\
\text { Name }\end{array}$ & $\begin{array}{c}\text { Fatty } \\
\text { Acids }\end{array}$ & $\begin{array}{c}\text { Compounds } \\
\text { Formula }\end{array}$ & $\begin{array}{c}\% \text {-m } \\
\text { (Chemical } \\
\text { Extraction) }\end{array}$ & $\begin{array}{c}\text { \%-m } \\
\text { (Mechanical } \\
\text { Extraction) }\end{array}$ \\
\hline $\begin{array}{c}\text { Octadecenoid } \\
\text { acid }\end{array}$ & $\begin{array}{c}\text { Oleic } \\
\text { acid }\end{array}$ & $\mathrm{C}_{18} \mathrm{H}_{34} \mathrm{O}_{2}$ & 34.74 & 23.62 \\
$\begin{array}{c}\text { Octadecadienoic Linoleic } \\
\text { acid }\end{array}$ & $\mathrm{C}_{18} \mathrm{H}_{34} \mathrm{O}_{2}$ & 23.54 & 20.39 \\
\hline $\begin{array}{c}\text { acid } \\
\text { fnstty acid }\end{array}$ & & & 58.28 & 44.01 \\
\hline $\begin{array}{c}\text { Octadekanoic } \\
\text { acid }\end{array}$ & $\begin{array}{c}\text { Stearic } \\
\text { acid }\end{array}$ & $\mathrm{C}_{18} \mathrm{H}_{36} \mathrm{O}_{2}$ & 18.93 & 17.99 \\
$\begin{array}{c}\text { Hexadecanoic } \\
\text { acid }\end{array}$ & $\begin{array}{c}\text { Palmitic } \\
\text { acid }\end{array}$ & $\mathrm{C}_{16} \mathrm{H}_{32} \mathrm{O}_{2}$ & 14.17 & 20.19 \\
\hline $\begin{array}{c}\text { SSaturated } \\
\text { fatty acid }\end{array}$ & & & 33.10 & 38.18 \\
\hline
\end{tabular}

\section{Conclusion}

In this study, it can be concluded that both hydraulic press and Soxhlet extraction yield nyamplung oil that has relatively similar saponification value, acid value, and iodine value. Nevertheless, in term of the fatty acid composition, slightly different percentages of the composition are obtained for nyamplung oil extracted. The chemical extraction yielded higher oleic acid compared to mechanical extraction while the opposite result was observed for palmitic acid. The overall oil yield obtained via mechanical yield is comparable to oil yield from Soxhlet extraction. Thus, the mechanical extraction by using hydraulic press could be applied for retrieving nyamplung oil. Further study is required to investigate the production routes for converting nyamplung oil to biohydrocarbon fuels.

\section{Acknowledgements}

This research was supported by the funding of Direktorat Riset dan Pengabdian Masyarakat, Direktorat Jenderal Penguatan Riset dan Pengembangan Kementerian Riset, Teknologi, dan Pendidikan Tinggi (Ristekdikti) Indonesia.

\section{References}

Atabani, A.E., and Cesar, A.S., 2014, Calophyllum inophyllum L. -A prospective non-edible biodiesel feedstock. Study of biodiesel production, properties, fatty acid composition, blending and engine performance, Renew. Sust. Energ. Rev, 37, 844-855.

Balaji, G., and Cheralathan, M., 2013, Potential of various sources for biodiesel production, Energy Sources Part A-Recovery Utilization and Environmental Effects, 831-839.

Bhuiya, M.M.K., Rasul, M.G., Khan, M.M.K., Ashwath, Azad, A.K., and Mofijur, M., 2015, Optimisation of oil extraction process from Australian native beauty leaf seed (Calophyllum inophyllum), Energy Procedia, 75, 56-61.

Dasari, S.R. and Goud, V.V., 2013, Comparative extraction of castor seed oil using polar and non-polar solvents, IJCET, 1 (special issue), 121-123.

Dewajani, H., Rochmadi, Purwono, S., and Budiman, A., 2015, Catalytic cracking of Indonesian nyamplung oil (Calophyllum 
inophyllum) for bio-fuels production using ZSM-5 catalyst, JESTEC, 61-69.

Goldman Sachs Group, 2008, The fundamental factors behind rising food and fuel prices.

Hasibuan, S., Sahirman, and Yudawati, N.M.A., 2013, Karakteristik fisikokimia dan antibakteri hasil purifikasi minyak biji nyamplung (Calophyllum inophyllum L.), Agritech, 33 (3), 311-319.

Knothe, G., 2002, Structure indices in FA chemistry. How relevant is the iodine value? J. Am. Oil Chem. Soc., 79(9), 847-854.

Jahirul, M. I., Brown, R.J., Senadeera, W., Ashwath, N., Laing, C., Leski-Taylor, J., and Rasul, M.G., 2013, Optimisation of bio-oil extraction process from beauty leaf (Callophyllum inophyllum) oil seed as a second generation biodiesel source, Procedia Engineering, 56, 619-624.

Jahirul, M.I., Brown, R.J., Senadeera, W., Ashwath, N., Rasul, M.G., and Rahman M.M., 2015, Physiochemical assessment of beauty leaf (Calophyllum inophyllum) as second-generation biodiesel feedstock, Energy Reports, 1, 204-215.

Kartika, I.A., Fathiyah, S., Desrial, and Purwanto, Y.A., 2010, Pemurnian minyak nyamplung dan aplikasinya sebagai bahan bakar nabati, Jurnal Teknologi Industri Pertanian, 20 (2), 122-129.

Kartika, I.A., Sari, D.D.K., Pahan, A.F., Suparno, O., and Ariono, D., 2017, Ekstraksi minyak dan resin nyamplung dengan campuran pelarut heksan-etanol, Jurnal Teknologi Industri Pertanian, 27 (2), 161-171.

Madsen, A. T., 2011, Catalytic Production of Biodiesel, Ph.D. thesis, Technical University of Denmark.
Ministry of Forestry of the Republic of Indonesia (The Forestry Research and Development Agency), 2008, Nyamplung Calophyllum inophyllum L: Sumber energi biofuel yang potensial, Jakarta, Indonesia.

Ramaraju, A. and Ashok Kumar, T.V., 2011. Biodiesel development from high free fatty acid punnakka oil, ARPN JEAS, 6 (4), 1-6.

Rizwanul Fattah, I.M., Kalam, M.A., Masjuki, H.H., and Wakil, M.A., 2014, Biodiesel production, characterization, engine performance, and emission characteristics of Malaysian Alexandrian laurel oil, RSC Adv., 4, 17787-17796.

Sahoo, P.K., and Das, L.M., 2009, Process optimization for biodiesel production from jatropha, karanja and polanga oils, Fuel, 88 (9), 1588-94.

Sahoo, P.K., Das, L.M., Babu, M.K.G., and Naik, S.N., 2007, Biodiesel development from high acid value polanga seed oil and performance evaluation in a CI engine, Fuel, 86 (3), 44854

Sari, E., 2013, Green diesel production via catalytic hydrogenation/decarboxylation of triglycerides and fatty acids of vegetable oil and brown grease, Ph.D thesis, Wayne State University.

U.S. Department of Energy, 2007, Basic Research Needs: Catalysis for Energy. https://science.energy.gov/ /media/bes/pdf/re ports/2017/BRN_CatalysisScience_rpt.pdf. 